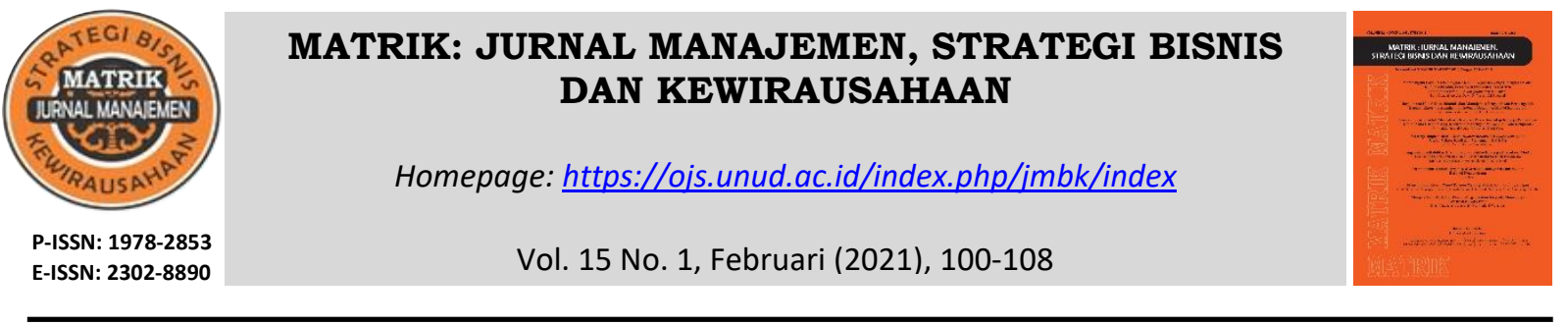

\title{
E-S-Qual and E-RecS-Qual Toward Customer Satisfaction, Trust and Loyalty in Electronic Banking Services during the Covid-19 pandemic
}

\section{Ramadania}

Fakultas Ekonomi dan Bisnis Universitas Tanjungpura email: ramadhania@ekonomi.untan.ac.id

\section{DOI : https://doi.org/10.24843/MATRIK:JMBK.2021.v15.i01.p09}

\begin{abstract}
During the pandemic, many countries has adopted physical \& social distancing policies, lockdowns, or territorial quarantine. Therefore the use of electronic banking services has increased sharply, including in developing countries such as Indonesia. Electronic banking services that are popularly used by many customers are in the form of internet banking and mobile banking. This study aimed to analyze; 1) the impact of the core online service quality (E-S-QUAL) on customer satisfaction, 2) the effect e-recovery service quality (E-RecS-QUAL) on satisfaction, 3) the effect of satisfaction on customer trust and 4) the effect of trust on customer loyalty. This research is causality research or explanatory research. The data collected by survey method to 120 respondents from customers who are registered users of e-banking (i.e. internet banking or mobile banking) from Mandiri, BCA, and Bukopin Bank. The results showed that the core online service quality (E-S-QUAL) and e-recovery service quality (E-RecS-QUAL) proved to have a positive influence on customer satisfaction. This research also proves the strong positive relationship between satisfaction and trust, as well as trust also has been shown to have a strong influence on customer loyalty.
\end{abstract}

Keyword: e-banking, e-s-qual, e-recs-qual, satisfaction, trust dan loyalty

\section{E-S-Qual dan E-RecS-Qual Menuju Kepuasan, Kepercayaan dan Loyalitas Nasabah dalam Layanan Perbankan Elektronik saat pandemi Covid-19}

\begin{abstract}
ABSTRAK
Selama pandemi, banyak negara mengadopsi kebijakan physical \& social distancing, lockdown, atau karantina wilayah. Oleh karena itu penggunaan layanan perbankan elektronik mengalami peningkatan yang cukup tajam, termasuk di negara berkembang seperti Indonesia. Layanan perbankan elektronik yang banyak digunakan nasabah berupa internet banking dan mobile banking. Penelitian ini bertujuan untuk menganalisis; 1) pengaruh kualitas layanan inti online (E-S-QUAL) terhadap kepuasan pelanggan, 2) pengaruh kualitas layanan e-recovery (E-RecS-QUAL) terhadap kepuasan, 3) pengaruh kepuasan terhadap kepercayaan pelanggan dan 4) pengaruh kepercayaan terhadap loyalitas pelanggan. Penelitian ini merupakan penelitian kausalitas atau penelitian eksplanatori. Pengumpulan data dilakukan dengan metode survei kepada 120 responden dari nasabah pengguna e-banking terdaftar (internet banking atau mobile banking) dari Bank Mandiri, BCA, dan Bank Bukopin. Hasil penelitian menunjukkan bahwa kualitas layanan inti online (E-S-QUAL) dan kualitas layanan e-recovery (E$\operatorname{Rec} S-Q U A L)$ terbukti berpengaruh positif terhadap kepuasan pelanggan. Penelitian ini juga membuktikan hubungan positif yang kuat antara kepuasan dan kepercayaan, serta kepercayaan juga terbukti memiliki pengaruh yang kuat terhadap loyalitas pelanggan.
\end{abstract}

Kata kunci: e-banking, e-s-qual, e-recs-qual, kepuasan, kepercayaan dan loyalitas 


\section{INTRODUCTION}

During the Covid-19 pandemic, many countries including Indonesia has implemented physical and social distancing, lockdown, or regional quarantine policies. This has an impact on increasing digital transactions during a pandemic. The same is the case with electronic banking services, where customers are more likely to use internet banking or mobile banking for digital payments. Customers will feel safer because it reduces crowded places and physical contact to avoid being infected with the covid. Research from the IMF, released in July 2020, states that the use of digital financial services during the 2017-2019 period (pre-covid-19) in emerging and developing economies has increased quite rapidly. The use of digital payments is an opportunity to support physical \& social distancing policies in reducing the spread of covid-19, (Agur et al., 2020). E-banking has been implemented in many developed countries such as the United States and Europe, and there is a growing trend in the adoption of e-banking by banks in developing countries (Chalantone, et al., 2006). Likewise in Indonesia, according to a bisnis.com report dated July 26, 2020, the use of digital banking during the pandemic has increased rapidly (Wiratmini, 2020). The same thing was conveyed by suaramerdeka.com on June 24, 2020, that the use of mobile banking and e-money during the pandemic has increased sharply by $50 \%$ (Dwi, 2020).

In the use of electronic banking in both internet banking and mobile banking, service is an important factor in creating customer satisfaction, trust, and loyalty. Hammoud et al. (2018) states that e-banking is a very important banking service, if done correctly it can increase customer satisfaction and create a competitive advantage for the bank. A literature review in the study of Zeithaml, Parasuraman \& Malhotra (2000) states that customer assessment of website quality includes all phases not only of experiences during customer interactions with sites but also aspects of post-interaction services (such as fulfillment, returns). Therefore Parasuraman et al., (2005) define e-SQ broadly to include all phases of customer interaction with Web sites, namely the extent to which Web sites facilitate efficient and effective shopping, purchasing, and delivery.

Zeithaml et al., (2002) have identified seven dimensions of online service quality, namely: efficiency, reliability, fulfillment, privacy, responsiveness, compensation, and contact. Parasuraman, Zeithaml \& Malhotra (2005) in their research redevelop the electronic service quality (e-SQ) measurement scale which focuses on two main elements, namely core online service (E-S-QUAL) and online service recovery (E-ResS-QUAL). Measurement of E-SQUAL includes four dimensions: (1) efficiency, namely the ease and speed of accessing and using the company website; (2) fulfillment, namely the accuracy of service promises, product stock availability, and product delivery according to the promised time); (3) system availability, namely the technical functionality of the site that operates properly; and (4) privacy, namely the level of site security and protection of customer information. The measurement dimensions of E-RecS-QUAL consist of (1) responsiveness, namely handling problems and returning products effectively through the mechanisms on the site, (2) compensation, namely the extent to which the site compensates customers for the problems that occur; and (3) contact, namely the availability of assistance via telephone or online staff.

Service quality is one of the keys to success to survive in increasingly competitive conditions. So that a company is expected to be able to retain and attract consumers and have more value than its competitors. Companies must also be able to provide services by following per under consumer desires and be able to satisfy consumers. According to academics, customer satisfaction is a stand-alone construct and is influenced by service quality (Oliver, 1980). Low quality will cause dissatisfaction with customers, not only these customers but also 
impact on others. Because a disappointed customer will tell at least 15 other people. As a result, prospective customers will make their choice of competitors (Lupiyoadi and Hamdani, 2006).

According to Kotler \& Keller (2006: 136) satisfaction is a feeling of pleasure or disappointment in someone who arises after comparing their perceptions or impressions of the performance or results of a product and their expectations. Customer satisfaction is customer satisfaction with electronic banking services that he feels or receives, after comparing it with the expected service. Raza et al. (2020) in their study found that all dimensions of internet banking service quality have a positive influence on customer satisfaction, furthermore customer satisfaction also has a positive influence on customer loyalty. Customer perceived satisfaction will increase trust. Morgan \& Hunt, (1994) stated that trust can affect loyalty or commitment because trust factors can create very valuable exchange relationships

Several studies have shown that e-service quality influences e-satisfaction, (Dhurup et al., 2014; Ariff et al., 2013; Tambusai et al., 2019; Tharanikaran et al., 2017; Salehnia et al., 2014). Among these studies also tested the relationship between satisfaction and loyalty (Ariff et al., 2013; Dhurup et al., 2014; Tambusai et al., 2019). However, there are still limited studies that examine the relationship between E-SQUAL and E-RecSQUAL and their interactions with satisfaction, trust, and loyalty in a model of electronic banking services. In fact, in the marketing literature as stated by Morgant \& Hunt (1994) trust is an important factor in building loyalty. A study conducted by Salehnia et al., (2014) in Iran on electronic banking services found that e-satisfaction has a strong positive effect on e-trust, as well as e-trust has a strong positive effect on e-loyalty. Therefore, to fill this gap, apart from testing the service quality of electronic banking and satisfaction, this study also includes factors of trust in building customer loyalty.

This study aims to build and test the e-SQ model on customer loyalty by including satisfaction and trust as intermediaries in building loyalty to electronic banking services. This study contribution is as follows: 1) Developing a measurement scale for e-SQ with two dimensions, namely E-SQUAL and E-RecSQUAL which was initiated by (Parasuraman et al., 2005), on electronic banking services in developing countries, namely Indonesia during the pandemic. There is an increasing customers' needs for quality electronic banking services and the ability to recover from problems and failures in delivering bank electronic services. 2) This research views the importance of e-satisfaction and e-trust factors in building and maintaining bank customer loyalty. 3) This research also provides practical contributions to bank management in developing a marketing strategy based on electronic banking services.

\section{RESEARCH METHODS}

This research seeks to find a cause and effect relationship between several variables developed in management (Ferdinand, 2013: 7). The design is explanatory research by testing the hypothesis and explains the object being studied. Based on the research background, problem formulation and research objectives, the main hypotheses in this study are as follows H1: Core online service quality (E-S-QUAL) has a positive effect on customer satisfaction. H2: E-recovery service quality (E-RecS-QUAL) has a positive effect on satisfaction. H3: Satisfaction has a positive effect on customer trust. H4: Trust has a positive effect on loyalty.

Data collection used a survey method by distributing questionnaires to 120 respondents in three banks, namely, Bank Mandiri, Bank BCA, and Bank Bukopin. Measurement of variable indicators used a Likert scale from $1=$ strongly disagree to $5=$ strongly agree. The ESQUAL variable uses measurements from Parasuraman, Zeithaml \& Malhotra (2005) which consist of 1) efficiency, 2) fulfillment, 3) system availability, 4) privacy. The E-RecSQUAL variable also uses measurements from Parasuraman et al., (2005) which consist of 1) responsiveness, 2) compensation, and 3) contact. Satisfaction using measurements from Yang et al. (2004) \& Rod et al. (2009) which consists of 3 items, namely: 1) overall, I am satisfied 
with the electronic banking services which I received, 2) overall, I am satisfied with the electronic-based transactions from this bank, 3) overall, I am satisfied with the products or services offered by the bank.

Trust is measured using 3 items, namely: 1) I trust the technological capabilities of this bank. 2) I trust the reputation of this bank. 3) I trust e-banking transactions at this bank because it is not risky. Loyalty is measured using 4 items, namely: 1) I will use e-banking services from this bank repeatedly, 2) I use other services offered by this bank, 3) I will recommend e-banking services from this bank to others, 4, I don't interested in using e-banking services by other banks.

Data analysis in this study used SEM-PLS with Warp-PLS v.6.0 software. PLS analysis uses two stages, first, evaluating the outer model to test the validity and reliability of the data. The data validity was done by testing convergent validity, discriminant validity, and average variance extracted (AVE). Meanwhile, reliability was tested with composite reliability and alpha Cronbach. Second, the evaluation of the inner model. This is done so that the model has a Goodness of Fit Model. The criteria for a good model are based on the index criteria as in Table 3. After that, the hypothesis testing is done.

\section{RESULT AND DISCUSSION}

Table 1.Testing of Convergent Validity \& AVE

\begin{tabular}{|c|c|c|c|}
\hline Construct & Measurement item & Loading & AVE \\
\hline \multirow[t]{12}{*}{ E-S-QUAL } & Efficiency-1 & 0.837 & 0.564 \\
\hline & Efficiency-2 & 0.798 & \\
\hline & Efficiency-3 & 0.707 & \\
\hline & Fulfillment-1 & 0.683 & \\
\hline & Fulfillment-2 & 0.666 & \\
\hline & Fulfillment-3 & 0.671 & \\
\hline & System availability-1 & 0.680 & \\
\hline & System availability-2 & 0.733 & \\
\hline & System availability-3 & 0.810 & \\
\hline & Privacy-1 & 0.856 & \\
\hline & Privacy-2 & 0.821 & \\
\hline & Privacy-3 & 0.712 & \\
\hline \multirow[t]{9}{*}{ E-RecS-QUAL } & Responsiveness-1 & Item Deleted & 0.716 \\
\hline & Responsiveness-2 & 0.839 & \\
\hline & Responsiveness-3 & 0.907 & \\
\hline & Compensation-1 & 0.864 & \\
\hline & Compensation-2 & 0.899 & \\
\hline & Compensation-3 & 0.852 & \\
\hline & Contact-1 & 0.854 & \\
\hline & Contact-2 & Item Deleted & \\
\hline & Contact-3 & 0.686 & \\
\hline \multirow[t]{3}{*}{ E-Satisfaction } & Satisfaction-1 & 0.672 & 0.548 \\
\hline & Satisfaction-2 & 0.883 & \\
\hline & Satisfaction-3 & 0.643 & \\
\hline \multirow[t]{3}{*}{ E-Trust } & Trust-1 & 0.688 & 0.601 \\
\hline & Trust-2 & 0.826 & \\
\hline & Trust-3 & 0.803 & \\
\hline
\end{tabular}




\begin{tabular}{llll}
\hline Construct & Measurement item & Loading & AVE \\
\hline E-Loyalty & Loyal-1 & 0.775 & 0,592 \\
\hline & Loyal-2 & 0.700 & \\
\hline & Loyal-3 & 0.829 & \\
\hline Loyal-4 & Item Deleted & \\
\hline
\end{tabular}

Ghozali (2008:24) reveals that the convergent validity test on the measurement model with a reflective indicator is assessed by the correlation between the item score/component score. Individual reflective measures can be said to be high if they are correlated with more than 0.70 in the measured construct. However, according to Chin, 1998 (Ghozali, 2008:24 ) in the early stages of research, the loading value of 0.5 to 0.6 was considered sufficient for the development of a measurement scale. This study will use a loading factor limit of 0.60 . Analysis on the outher model shows that there are three items, namely, Responsiveness-1 (0.568), Contact-2 (0.403), and Loyal-4 (0.522) which have a loading factor value below 0.6. These three items will be deleted in the next analysis as stated in Table 1.

Tabel 2. Testing of Reliability

\begin{tabular}{lll}
\hline Construct & $\begin{array}{l}\text { Composite Reliability } \\
\text { Coefficients }\end{array}$ & $\begin{array}{l}\text { Cronbach's Alpha } \\
\text { Coefficients }\end{array}$ \\
\hline E-S-QUAL & 0.939 & 0.929 \\
\hline E-RecS-QUAL & 0.946 & 0.932 \\
\hline E-Satisfaction & 0.781 & 0.573 \\
\hline E-Trust & 0.818 & 0.664 \\
\hline E-Loyalty & 0.813 & 0.653 \\
\hline
\end{tabular}

\section{Inner Model Testing.}

The results of the SEM-PLS analysis with the Warp-PLS software provide the results of the value of the fit and quality indices model as shown in Table 3.

Table 3. Model of fit and quality indices

\begin{tabular}{|c|c|c|c|c|}
\hline No. & Model fit and quality indices & Fit Criteria & $\begin{array}{l}\text { Analysis } \\
\text { Results }\end{array}$ & Information \\
\hline 1 & Average path coefficient (APC) & $\mathrm{P}<0.05$ & $\begin{array}{l}0.528 \\
(\mathrm{P}<0.001)\end{array}$ & Good \\
\hline 2 & Average R-squared (ARS) & $\mathrm{P}<0.05$ & $\begin{array}{l}0.510 \\
(\mathrm{P}<0.001)\end{array}$ & Good \\
\hline 3 & Average adjusted R-squared (AARS) & $\mathrm{P}<0.05$ & $\begin{array}{l}0.504 \\
(\mathrm{P}<0.001)\end{array}$ & Good \\
\hline 4 & Average block VIF (AVIF) & $\begin{array}{l}\text { acceptable if }<=5, \\
\text { ideally }<=3.3\end{array}$ & 8,915 & Poor \\
\hline 5 & Average full collinearity VIF (AFVIF) & $\begin{array}{l}\text { acceptable if }<=5, \\
\text { ideally }<=3.3\end{array}$ & 6.117 & Poor \\
\hline 6 & Tenenhaus GoF (GoF) & $\begin{array}{l}\text { small }>=0.1, \text { medium }>= \\
0.25, \text { large }>=0.36\end{array}$ & 0.555 & Ideal \\
\hline 7 & Sympson's paradox ratio (SPR) & $\begin{array}{l}\text { acceptable if }>=0.7, \\
\text { ideally }=1\end{array}$ & 1.000 & Ideal \\
\hline 8 & R-squared contribution ratio (RSCR) & $\begin{array}{l}\text { acceptable if }>=0.9 \text {, } \\
\text { ideally }=1\end{array}$ & 1.000 & Ideal \\
\hline 9 & Statistical suppression ratio (SSR) & acceptable if $>=0.7$ & 1.000 & Ideal \\
\hline 10 & $\begin{array}{l}\text { Nonlinear bivariate causality direction } \\
\text { ratio (NLBCDR) }\end{array}$ & acceptable if $>=0.7$ & 1.000 & Ideal \\
\hline
\end{tabular}


In general, the inner model test in Table 3 shows that most of the model goodness index values have met the recommended criteria (APC, ARS, AARS. GoF, SPR, RSCR, SSR, and NLBCDR), except for the AVIF index (no.4). and AFVIF (no.5). However, the criteria listed in Table 3 act as the rule of thumb, so they do not apply rigidly and absolutely. If there are one or two indicators of the fit and quality indices that do not meet the criteria, the model can still be used (Solimun et al., 2017).

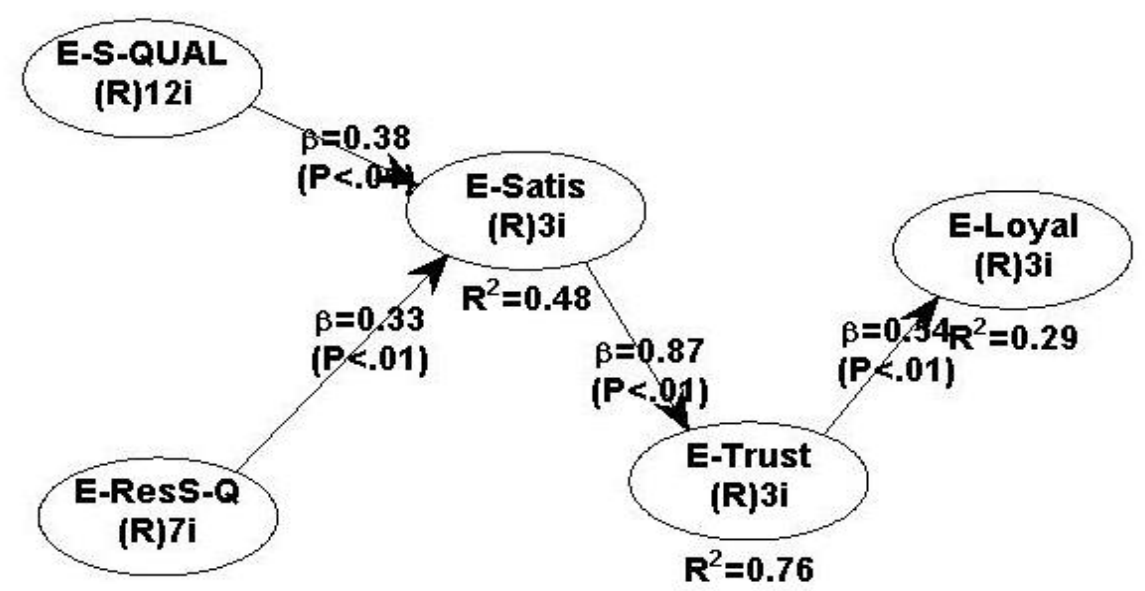

Figure 1.The Results of the Structural Model Analysis (Inner Model)

From the data processing of Warp-PLS, the $\mathrm{R}^{2}$ value for satisfaction is 0.49 . $\mathrm{R}^{2}$ for trust is 0.76 and loyalty $\mathrm{R}^{2}$ is 0.38 . The $\mathrm{R}^{2}$ satisfaction value of 0.49 means that the contribution of the E-SQUAL and E-RecS-QUAL variables to the satisfaction variable is $49 \%$ and the remaining $51 \%$ is influenced by other variables outside of this research model and error. The $\mathrm{R}^{2}$ value of the trust variable is 0.76 , which means that the contribution of the influence of the e-satisfaction variable on e-trust is $76 \%$ and the rest is the influence of other factors outside the research model. Likewise, the $\mathrm{R}^{2}$ value of the loyalty variable of 0.38 means that the contribution of the e-trust variable to the e-loyalty variable is $38 \%$ and the rest is explained by other variables outside the model. Table 4 shows the path analysis.

Table 4. Hypothesis test

\begin{tabular}{cccc}
\hline Path & Beta & Sig $(\mathbf{P})$ & Note \\
\hline E-SQUAL --> E-SATISFACTION & 0.376 & $\mathrm{P}<0.001$ & H1: Accepted \\
\hline $\begin{array}{c}\text { E-RecS-QUAL --> E- } \\
\text { SATISFACTION }\end{array}$ & 0.330 & $\mathrm{P}<0,001$ & H2: Accepted \\
\hline E-SATISFACTION --> E-TRUST & 0.871 & $\mathrm{P}<0,001$ & H3: Accepted \\
\hline E-TRUST --> E-LOYAL & 0.536 & $\mathrm{P}<0,001$ & H4: Accepted \\
\hline
\end{tabular}

As presented in Table 4, the hypotheses of $\mathrm{H} 1, \mathrm{H} 2, \mathrm{H} 3, \mathrm{H} 4$ on the structural model (inner model) are tested using the t-test. H1: It is assumed that E-S. QUAL influences 
satisfaction. The test results indicate that E-SQUAL influences the Satisfaction Beta value of 0.30 , with a significance of $\mathrm{P}<0.01$. Thus $\mathrm{H} 1$ is accepted. This means that E-SQUAL is proven to influence e-satisfaction. H2: It is expected that E-RecS-QUAL influences satisfaction. The results of path analysis testing with a t-test shows that the effect of E-RecS-QUAL on satisfaction has a Beta of 0.41 , with a significance of $\mathrm{P}<0.01$. E-RecS-QUAL has a strong positive influence on satisfaction. Thus $\mathrm{H} 2$ is accepted. This means that E-RecS-QUAL is proven to have a significant effect on e-satisfaction. H3: It is expected that satisfaction has an effect on trust. The results of path analysis with the t-test shows that satisfaction has an influence on trust with a Beta value of 0.87 with a significance of $\mathrm{P}<0.01$. This means that satisfaction has a significant effect on trust, thus $\mathrm{H} 3$ is accepted. H4: It is expected that satisfaction has a trusted effect. The results of path analysis testing with the t-test show that trust has an influence on loyalty with a Beta value of 0.61 with a significance of $\mathrm{P}<0.01$. This means that trust has a significant influence on loyalty. Thus $\mathrm{H} 4$ is accepted.

Therefore, it can be concluded based on the above analysis that all hypotheses in this study are accepted. That means that H1: Core online service quality (E-S-QUAL) has a significant effect on E-Satisfaction on Internet Banking. The research supports the findings of Dhurup et al., 2014; Ariff et al., 2013; Tambusai et al., 2019; Tharanikaran et al., 2017; Salehnia et al., 2014, Raza et al.2020). H2: E-recovery service quality (E-RecS-QUAL) has a significant effect on E-Satisfaction. H3: E-Satisfaction has a significant effect on E-Trust, this is in line with the findings of Salehnia et al., (2014). H4: E-Trust has a significant effect on Eloyalty in the context of e-banking services as is the finding in the study of Salehnia et al., (2014).

This research shows the importance of managing a good e-SQ to realize long-term relationships with customers. This e-SQ improvement strategy mainly focuses on two important dimensions, namely core online service quality (ES-QUAL) which consists of 1) efficiency, 2) fulfillment, 3) system availability, 4) privacy, and e-recovery service quality (ERecS-QUAL) which consists of responsiveness, compensation, and contacts. The delivery of these services in electronic banking such as internet banking or mobile baking must be as good as handling problems in service delivery and recovering from failures in service delivery. This will also be closely related to handling customer complaints. Service delivery and service recovery are handled in a manner that will create customer satisfaction and trust. In the end, the company will get profit through increasing customer loyalty, thus the relationship marketing theory initiated by Morgan \& Hunt (2014) in which trust is an important factor in building long-term relationships with customers is supported by this study.

Overall this research model has developed and supported the ideas of Zeithaml et al., (2000), (2002) and Parasuraman et al., (2005) into the practice of e-banking services marketing strategy. This can be an opportunity and solution to support physical and social distancing policies during pandemic, by providing a sense of comfort and safety for customers and avoiding crowded places or public facilities. Also, this can avoid face to face contact with other people which can help reduce the rate of covid spread.

\section{CONCLUSION \& IMPLICATION}

Testing the e-SQ model on customer loyalty by including satisfaction and trust as an intermediary in building loyalty to electronic banking services can be said to be good because it has a goodness of fit model value. In general, the development of the e-SQ model in electronic banking services supports the concept of E-S-QUAL and E-RecS-QUAL which was initiated by (Zaithaml et al., 2000; Zeithaml et al., 2002; Parasuraman et al., 2005) in electronic banking services. in times of a pandemic.

All hypotheses proposed in this study are supported. E-SQUAL and E-RecS-QUAL are proven to have a positive effect on satisfaction. Satisfaction has a very strong positive influence 
on trust, as well as that trust has a very strong positive influence on customer loyalty.This research has provided important evidence of satisfaction and trust in building customer loyalty. Hence the practical implications for bank management is to focus on developing a marketing strategy for electronic-based services.

\section{REFERENCES}

Agur, I., Peria, S. M., \& Rochon, C. (2020). Digital Financial Services and the Pandemic: Opportunities and Risks for Emerging and Developing Economies. International Monetary Fund Special Issue on COVID-19, 1-13.

Ariff, M. S. M., Yun, L. O., Zakuan, N., \& Ismail, K. (2013). The Impacts of Service Quality and Customer Satisfaction on Customer Loyalty in Internet Banking. Procedia - Social and Behavioral Sciences, 81, 469-473. https://doi.org/10.1016/j.sbspro.2013.06.462

Calantone, R. J.. David A. Griffith dan Goksel Yalcinkaya. (2006). An Empirical Examination of a Technology Adoption for the Context of China. Journal of International Marketing, Vol 14: 1-27.

Dhurup, M., Surujlal, J., \& Redda, E. (2014). Customer perceptions of online banking service quality and its relationship with customer satisfaction and loyalty. Mediterranean Journal of Social Sciences, 5(8), 72-80. https://doi.org/10.5901/mjss.2014.v5n8p72

Dwi Setiady, 2020. Penggunaan Mobile Banking dan e-Money Meningkat Pesat https://www.suaramerdeka.com/news/ekonomi-dan-bisnis/232455-penggunaan-mobilebanking-dan-e-money-meningkat-pesat. suaramerdeka.com, Bandung. Rabu, 24 Juni 2020, jam 19:47 WIB

Ferdinand Agusty Tae. (2013). Metode Penelitian Manajemen: Pedoman Penelitian untuk skripsi, Tesis dan Disertai Ilmu Manajemen. Semarang: Universitas Diponegoro.

Ghozali, Imam. 2008. Structural Equation Modeling: Metode Alternatif dengan Partial Least Square (PLS). Edisi 2. Badan Penerbit Universitas Diponegoro.

Hammoud Jamil, Rima M. Bizri, Ibrahim El Baba. (2018). The Impact of E-Banking Service Quality on Customer Satisfaction: Evidence From the Lebanese Banking Sector. SAGE Open, 8(3). https://doi.org/10.1177/2158244018790633

Kotler Philip \& Keller Kevin Lane. (2006). Marketing Management 12e. Pearson International Edition. Pearson Prentice Hall

Lupiyoadi, Rambat dan A. Hamdani. Manajemen Pemasaran Jasa, edisi kedua. Jakarta: Salemba Empat, 2006.

Morgan, R. M., \& Hunt, S. D. (1994). The Commitment-Trust Theory of Relationship Marketing. Journal of Marketing, 58(3), 20. https://doi.org/10.2307/1252308

Parasuraman, A., Zeithaml, V. A., \& Malhotra, A. (2005). E-S-QUAL a multiple-item scale for assessing electronic service quality. Journal of Service Research, 7(3), 213-233. https://doi.org/10.1177/1094670504271156

Raza, S.A., Umer, A., Qureshi, M.A. and Dahri, A.S. (2020). Internet banking service quality, e-customer satisfaction and loyalty: the modified e-SERVQUAL model. The TQM Journal, Vol. 32 No. 6, pp. 1443-1466. https://doi.org/10.1108/TQM-02-2020-0019

Rod, M., Ashill, N. J., Shao, J., and Carruthers, J. (2009). An examination of the relationship between service quality dimensions, overall internet banking service quality and customer satisfaction: A New Zealand study. Marketing Intelligence \& Planning, 27(1), 103-126.

Salehnia, M., Saki, M., Eshaghi, A., \& Salehnia, N. (2014). A model of E-Loyalty and wordof-mouth based on e-trust in E-banking services (case study: Mellat Bank). 8th International Conference on E-Commerce in Developing Countries: With Focus on e- 
Trust, ECDC 2014, April. https://doi.org/10.1109/ECDC.2014.6836764

Solimun, Fernandes Adji Achmad Rinaldo, Nurjannah. (2017). Metode Statistika Multivariate: Pemodelan Persamaan Struktural (SEM), Pendekatan WarpPLS. UB Press.

Tambusai, S. R. K., Suharyono, \& Pangestuti, E. (2019). Pengaruh E-service Quality Dan Erecovery Service Quality Terhadap Perceived Value, E-customer Satisfaction Dan Ecustomer Loyalty ( Studi Pada Pelanggan Online Shopping Di Website. Profit, 13(2), 73-80.

Tharanikaran, V., Sritharan, S., \& Thusyanthy, V. (2017). Service Quality and Customer Satisfaction in Electronic Banking. International Journal of Business and Management, 12(4), 67. https://doi.org/10.5539/ijbm.v12n4p67

Wiratmini Ni Putu Eka. (2020). Judul Digital Banking Melesat, Tren Penutupan Kantor Cabang Bakal Berlanjut. https://finansial.bisnis.com/read/20200726/90/1271244/digitalbanking-melesat-tren-penutupan-kantor-cabang-bakal-berlanjut. Bisnis.com tanggal 26 Juli 2020, jam 13:38 WIB.

Yang, Z., Jun, M. and Peterson, R.T. (2004), "Measuring customer perceived online service quality: scale development and managerial implications", International Journal of Operations \& Production Management, Vol. 24 No. 11, pp. 1149-74.

Zeithaml, V. A., Parasuraman, A., \& Malhotra, A. (2002). Service Quality Delivery through Web Sites: A Critical Review of Extant Knowledge. Journal of the Academy of Marketing Science, 30(4), 362-375. https://doi.org/10.1177/009207002236911

, A. Parasuraman, and Arvind Malhotra. (2000). A Conceptual Framework for Understanding e-Service Quality: Implications for Future Research and Managerial Practice. Working paper, report No.00-115, Marketing Science Institute, Cambridge, MA. 